\title{
土砂災害地形の発生にかかわる現地形と植生変化の影響 一北部北上山地に扔ける検討例一
}

\author{
太田岳洋*，長谷川淳*，高見智之块，川村晃寛 ${ }^{* * *}$
}

\begin{abstract}
要 旨
硬質の堆積岩がほぼ一様に分布するとみなすことのできる北部北上山地の一地域について，気象条件がほぼ一定であった 1970 年〜2001 年の 6 時期の空中写真を用いて植生変化と土砂災害地形を判読した。 また 2000 年に航空レーザ測量で得られた数值標高モデル(DEM)を用 いて現地形を定量的に計測した。これらの結果から, 流域内における土砂災害地形の発生には, 流域の地形条件之植生の变化の両者が影 響することが明らかとなった，例えば，局所的な平均傾斜量や高度分散量の流域平均值が大きくなると流域内の単位面積あたりの崩壊箇 所数が増加し，また伐採によりコナラ・クリ・落葉広葉樹群落の流域内の分布面積が減少してあ崩壊箇所数が増加する。しかし，ほぼ全 域が伐採された流域でも平均傾斜量の流域平均が小さいと崩壊は発生せず，また平均傾斜量の流域平均や表面積比が大きい流域では植生 にかかわらず崩壊地などの土砂災害地形が増加する。これらのことから，災害発生を促進するような植生条件と斜面崩壊に影響する地形 因子とを適切に設定することにより，それらの值を用いて斜面崩壊などの土砂災害地形が発生・増加する可能性を評価できると推定され る.
\end{abstract}

Key words : 土砂災害地形 topography of landslide disaster, 空中写真判読 interpretation of aerial photograph, 地形計測 geomorphometric study, 植生 vegetation

\section{1. は じめ に}

自然斜面の崩壊や洛石，土石流など哭発的な土仯災害の 発生には, 降雨などの誘因とともに素因としての地形・地 質条件, 地下水条件や植生, 人工改変などの環境条件が関 与すると考えられる．このような土砂災害の発生には大小 の地形変化がと屯なうため, 地形と土砂災害の関係につい ては,これまでも多くの研究者により議論されている1). 近年は, 数值標高モデル (DEM)を用いた地形計測により, 自然災害の発生にかかわる地形条件を定量的に評価し，そ れをあとに災害危険箇所を予測する手法が試みられてい る ${ }^{2)}$. しかし, 現状では地形条件のみで定量的に精度よく 災害発生に関する評価を行うことは困難であり，植生など の環境条件や地質条件ああわせた定量的な評価手法の確立 が望まれている.

一方, 地形と植生の関係については, これまで環境保全

* (財)鉄道総合技術研究所 Railway Technical Research Institute (会員)

E-mail : ohta@rtri.or.jp

**国際航業(株) Kokusai Kogyo Co., LTD. (会員)

*** 北栄調査設計(株) Hokuei survey and design Co., LTD.
を目的とした地生態学的観点から議論されてきた に, 菊池は斜面崩壊地, 地すべり地や土石流堆積地などに おける植物群の特徴と成立過程をまとめている ${ }^{3)}$. このよ うな地生態学的な地形・植生関係の研究は, 現地形での植 物群の成立過程を述べるにとどまっている，また，砂防分 野では空中写真を用いた斜面崩壊後の植生回復状況の経年 的変遷に関する研究例 ${ }^{4)}$, 森林伐採や植栽面積の変化と流 域の土砂生産および崩壊面積の関係を論じた研究例 ${ }^{5), 6)}$ が あり, 武居》が土砂災害にかかわる地形条件をまとめてい る．砂防，治山における植生と土砂災害の関係については， 塚本 ${ }^{8)}$ が包括的に論じている.

本論では, 地形変化を土砂災害と読み替え, 地形条件や 植生環境の経時的な変化が土砂災害に及ぼす影響を明らか にすることを目的に, 硬質の堆積岩がほぼ一様に分布する 北部北上山地を対象として1970年以降の 6 時期に撮影され た空中写真から地形と植生の状況を判読し，2000年に作成 した $5 \mathrm{~m}$-DEMから各種地形量を算出した。本稿では, こ れらの結果にもとづいて地形や植生の経時変化と相互関係 について検討した結果を述べる。1970年代のLANDSAT 衛星以降, 植生などの環境条件の評価には衛星画像が用い られ ${ }^{9)}$, 最近は高分解能の衛星画像(例えばIKONOS画像) 
により災害斜面等の微小な範囲の解析も可能となっている。 このような衛星画像を用いることで前述の自然災害の定量 的な予測が可能になると考えられるが, 高分解能の衛星画 像は最近 4〜 5 年間のものしかなく, また地形判読に適用 可能なステレオ画像の配信が少ないことから今回は空中写 真を用いて検討することとした。

\section{2. 調査地域の概要}

\section{1 調査地域の選定条件}

今回は地形条件と植生条件が斜面崩壊や土石流などの土 砂災害地形の発生に与える影響を検討することを目的とし ているため，検討対象地域を選定する際には以下の条件を 満たすことを考慮した。

(1)地質条件の影響を排除するため, 応用地質学的条件(岩 種, 強度など)がある程度一様であると判断できる地域で あること。

(2)地域内の植生は均一ではなく, ある程度の多様性が認め られること。

(3)比較的多くの災害履歴が確認されていること. (4)特徴的な土砂災害地形を呈する地すべりについては, 変 化に要する時間が他の災害に比べ長期間にわたる場合があ り, 今回は検討対象としないので, 顕著な地すべりが存在 しないこと。

(5)調査対象期間とした1970年以降に，異常な降雨を経験し ていないこと.

以上を満足する地域として, 岩手県中部の三陸海岸より 約 $20 \mathrm{~km}$ 内陸に位置する北部北上山地の茂市周辺地域(図一

\section{1）を選定した.}

\section{2 地形・地質および植生の概要}

調查対象地域は標高100～600mの低山地地形を呈する. 対象地域南端部を西から東に流下する閉伊川および対象地 域東部を北西から南東に流下する刈屋川沿いには数段の段 丘面が認められ，とくに約 1 万年前に形成された鈴久名 面 ${ }^{10)}$ が広く分布する. 山地部と同様にこれらの段丘面も浸 食されており, 対象地域は刚屋川および閉伊川を浸食基準 面とする地域と判断される.

地質は葛巻一釜石帯 ${ }^{11}$ に相当し, 主に頁岩, 砂岩, チャー トおよびこれらの互層からなり，一部にレンズ状の石灰岩 やデイサイトの貫入岩が分布する (図-2) ${ }^{12)}$. これらの地層 はおおむ称北西一南東方向の走向で西に傾斜する。また， これらの地層は非浅海性堆積物が複雑に变形した付加体の 堆積物に相当すると考えられている ${ }^{13)}$. 現地踏査の結果, 対象地域は頁岩, 砂岩が主に分布し, チャートが狭在する ことを確認した。図-2では調査対象地域の閉伊川沿いに広 くチャートが分布するが, 現地踏査により周辺と同様に頁 岩, 砂岩主体であることを確認した. 以上から, 図-1に示 した調査対象地域は応用地質学的には硬質の堆積岩と一括 できると判断した.

また, 当該地域では後水期にブナ林が成立したと推定さ れ ${ }^{14)}$, 植生区分としてはブナクラス域(落葉広葉樹) とヤブ ツバキクラス域(常緑広葉樹)の境界付近に位置する。しか し, 中世末より木炭生産のための伐採が行われるようにな り, 1940年と1953年に木炭生産のピークを迎え, 地域全体 がほぼ落葉広葉樹の二次林で占められるようになった ${ }^{15)}$.

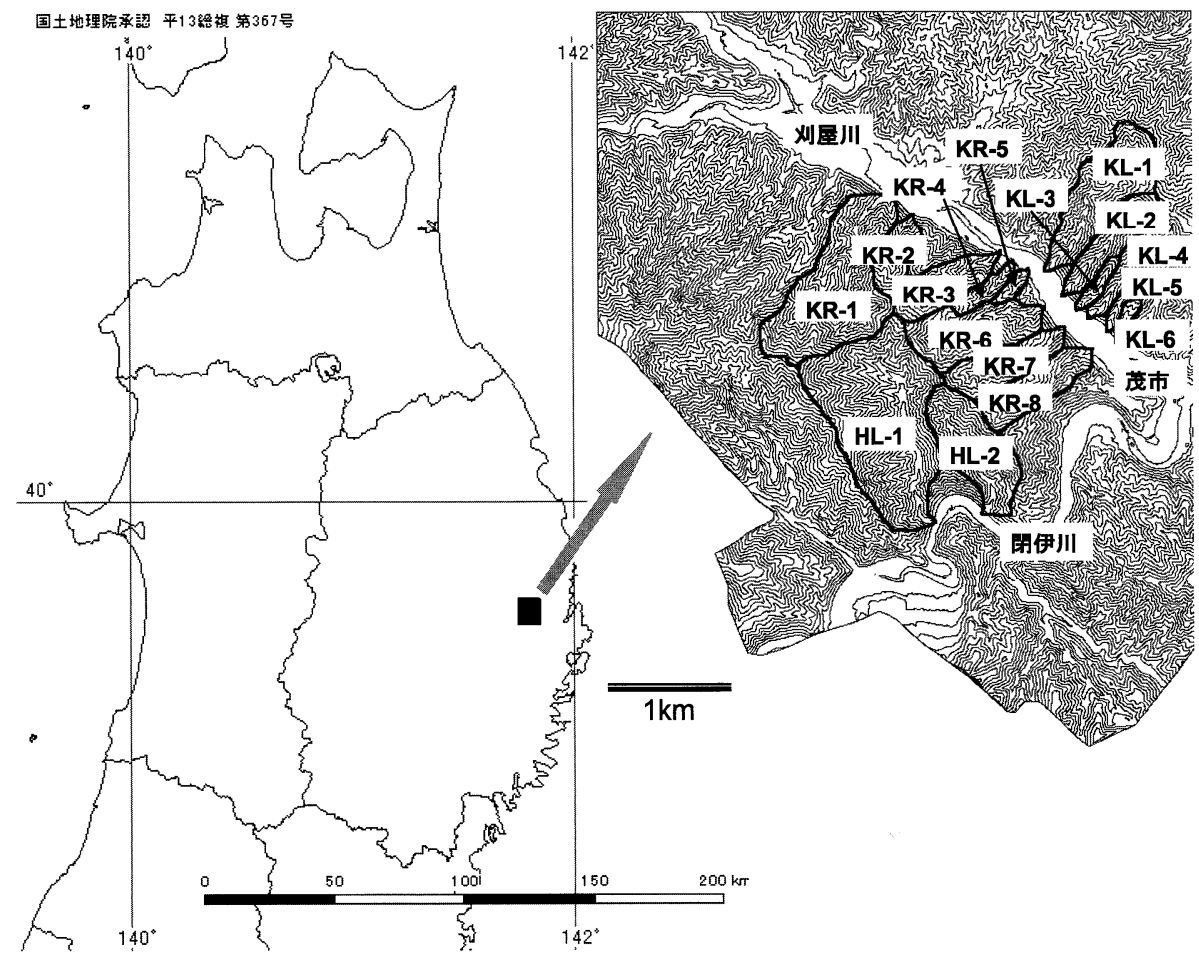

図-1 検討対象地域の位置亡地形

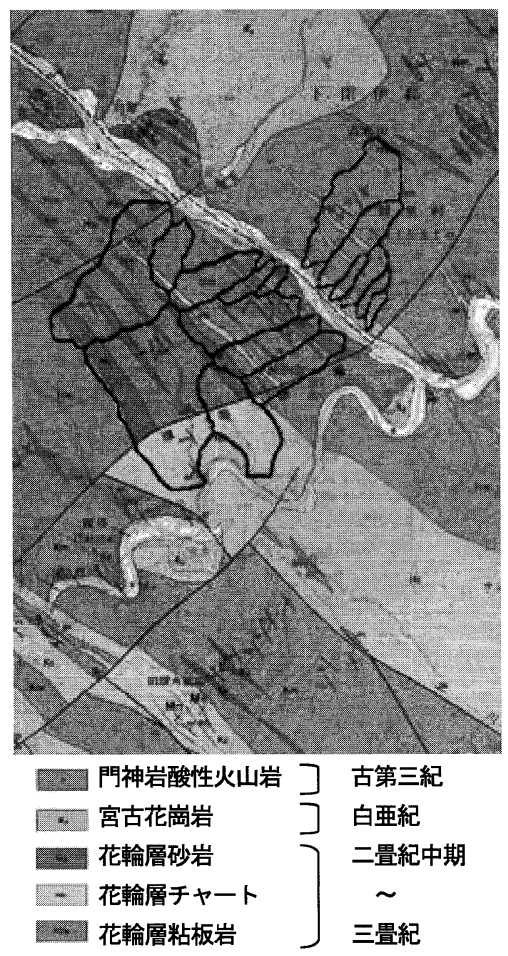

図-2 対象地域周辺の地質 ${ }^{12)}$ 
なお，木炭生産のための伐採は25〜30年間隔で行われてい た. 環境省が実施した第 5 回自然環境保全基礎調査の植生 調査報告書 ${ }^{16)}$ では, 対象地域の植生はブナクラス域代償植 生のクリーミズナラ群落，ススキ群団，ヤブッバキクラス 域代償植生のコナラ群落, その他にアカマツ植林, スギ・ ヒノキ・サワラ植林, 落葉針葉樹植林が分布するとされ, 植生の多様性があると判断される.

\section{3 調査地域における災害履歴}

当該地域周辺には，鉄道路線としてJR山田線，岩泉線， 国道は106号および340号がある．鉄道沿線では，落石や斜 面崩壊などの災害が繰り返し発生している。また，道路で 屯後述の通常の降雨にともない斜面崩壊などが頻発し， 「特定地域に係る激甚災害指定」を繰り返し受けている.

対象地域については1999，2002，2003年に現地踏査を行っ たが，その際に植生の分布しないごく新しい時期に堆積し たと推定される土石流堆積物や山腹斜面の崩壊地を複数箇 所で確認した。また，後述の空中写真判読の結果，継続的 に滑動しているような地すべり地形は認められなかった。

\section{4 調査地域周辺の降雨履歴}

対象地域にもっとも近いアメダス地点「川井」(北緯39度 35.9 分，東経 141 度 40.9 分，調查地域加ら西南西へ約 $10 \mathrm{~km}$ ) の月最大日降水量の履歴を図-3に示す。「川井」地点の観 測データが1979年以降のみであるため，「宮古」測候所(北 緯39度38.8分，東経141度57.9分，調査地加ら東北東へ約 17 $\mathrm{km})$ における1970年以降の履歴も同図に示す。「川井」地

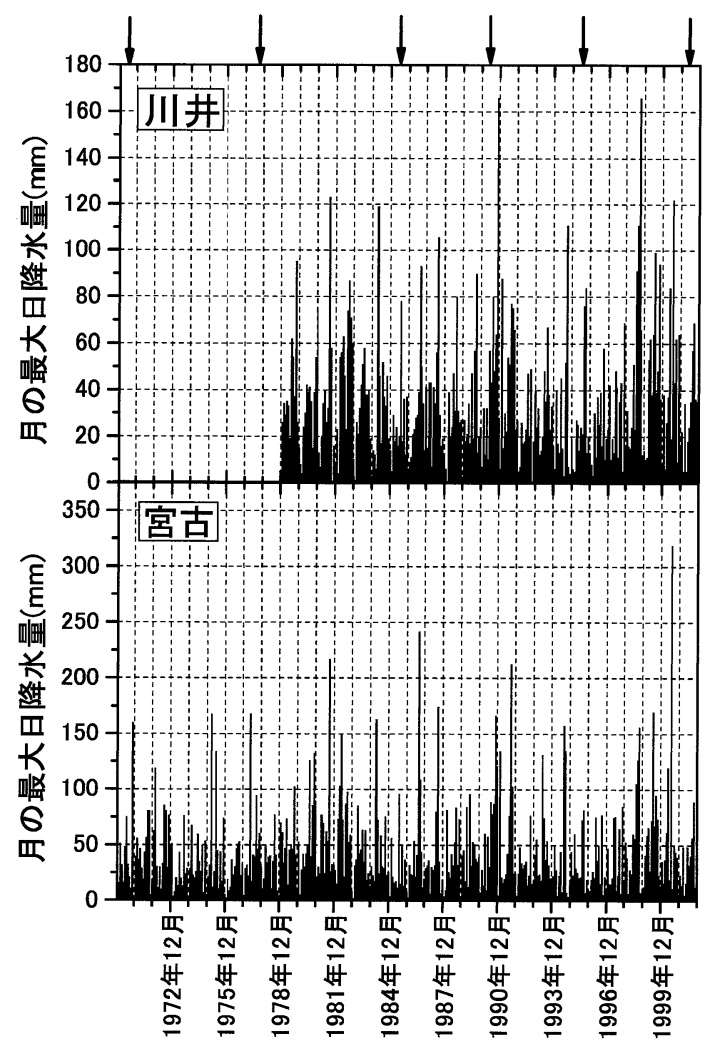

図-3 対象地域周辺の月ごと最大日降水量の履歴 矢印は表-3に示した空中写真の撮影時期を示す. 表-1＼cjkstart宮古および川井における年確率降水量

\begin{tabular}{ccc} 
& & $(\mathrm{mm})$ \\
\hline 確率年 & 宮古 & \multicolumn{1}{c}{ 川井 } \\
\hline 3 & 139.2 & 95.7 \\
\hline 5 & 164.6 & 111.7 \\
\hline 10 & 196.6 & 131.8 \\
\hline 30 & 244.9 & 162.3 \\
\hline 50 & 267.0 & 176.1 \\
\hline 100 & 296.7 & 194.9 \\
\hline 150 & 314.1 & 205.8 \\
\hline 200 & 326.4 & 213.6 \\
\hline
\end{tabular}

点では, 1979 年以降月最大日降水量が $100 \mathrm{~mm}$ 超えたのは 8 回であり，1990年11月と1998年10月には月最大日降水量 が160mmを超える降雨が観測されている。一方，「宮古」測 候所では 1970 年以降, $150 \mathrm{~mm}$ を超える月最大日降水量が 13 回観測され，2000年 7 月には $319 \mathrm{~mm}$ の月最大日降水量を記 録している. 図-3に示した月最大日降水量データから, 1970年から2000年の間には両観測地点ともに年による多少 の増減はあるものの, 年間を通じてはほぼ同様の月最大日 降水量の変動を示す降雨条件であったと考えることができ る. 表-1に両観測地点における年最大日降水量より求めた 年確率降水量を示す。「川井」地点では $100 \mathrm{~mm}$ の日降水量は $3 \sim 5$ 年確率であり， $160 \mathrm{~mm}$ はおおよう 30 年確率の降雨に相 当する.また，「宮古」測候所では $150 \mathrm{~mm}$ の日降水量は $3 \sim 5$ 年確率の降雨にあたり，2000年 7 月の $319 \mathrm{~mm}$ はおおよそ 150 年確率の降雨に相当する.

二戸市や九戸郡など岩手県北部では1999年10月27～28日 に豪雨があり，土砂災害む多く発生した。このとき「川井」 地点では月最大日降水量が約 30 年確率の $160 \mathrm{~mm}$ 超えてい るが，「宮古」測候所では120〜 130mm程度 (2〜3 年確率)で ある。これらのことから，このときの月最大日降水量む当 該地域周辺においては，2～ 5 年に 1 回程度発生する降水 量であると判断することができる。 また，「宮古」測候所 で約150年確率の $319 \mathrm{~mm}$ の日降水量を記録したときに，「川 井」地点では $5 \sim 10$ 年確率に相当する $122 \mathrm{~mm}$ の日降水量が 記録されている。調查地は「川井」地点により近いことか ら，このときには 5 年確率以上， 30 年確率以下の降雨があっ たと推定される.

以上から, 調査対象地域では2000年にやや強い強度の降 雨が観測されたものの，1970年以降は年単位としては，ほ ぼ同様の降雨条件であると判断することができる。

\section{3. 調 查 方 法}

\section{1 細密数值標高データによる地形計測}

調査地域の地形条件を定量的に把握するために，図-1に 示した調查対象範囲を含む刈屋川流域約 $48 \mathrm{~km}^{2}$ の範囲につ いて, 航空レーザ測量により格子点間隔が $5 \mathrm{~m}$ の数值標高 モデル(DEM)を作成し，それをむとに各種地形計測を行っ た. 


\begin{tabular}{|c|c|}
\hline 項 目 & $\begin{array}{ll}\text { 諸 } \\
\end{array}$ \\
\hline 計測高度 & 対地 $900 \mathrm{~m}$ \\
\hline 対地速度 & $50 \mathrm{~m} / \mathrm{s}$ \\
\hline スキャン角 & $\pm 20^{\circ}$ \\
\hline スキャン頻度 & $10 \mathrm{~Hz}$ \\
\hline レーザ高照射頻度 & $5,000 \mathrm{~Hz}$ \\
\hline コース数 & 30コース \\
\hline コース間ラップ & $30 \%$ \\
\hline データ間隔 & $2.5 \mathrm{~m}$ \\
\hline
\end{tabular}

航空レーザ測量では，航空機に搭載した $\mathrm{G}$ PSとIMU (慣性計測装置)によりレーザを送 受信する航空機の位置と姿勢を計測し，パル ス状に照射されたレーザ光が地表の樹木や地 面に反射して戻る時間を計測することにより， 航空機と地表の反射面との距離を計測する. 地表に樹木等がある場合には, 照射されたレー ザの一部は葉や枝で反射され, 残りの一部は 樹木の隙間から地表に到達するため, 樹木で の反射(ファーストパルス)から地面での反射 (ラストパルス)まで複数の反射光が観测され る.そのため, 地表面の標高値を得るために はラストパルスをデータとして取得し，この データからDEMを算出することとなる.

上記のような計測手法の原理から, 今回の 調査地域において精度よく地表面の標高值を 取得するためには, 広葉樹が落葉した後で, かつ降雪時期の前に測量を行うことが望まし いと考えられる。そこで，2000年11月下旬に 測量を実施した．測量の諸元を表-2に示す.

測量結果からDEMを作成する際, 明らか に植生の影響が認められる箇所については空 中写真などを参考に手動で修正を行った。こ のような植生の影響などによる測量の誤差がDEMに反映 されないように，スムージング処理を行って得られた標高 データを用いて地形計測を行った。

DEMを用いた局所地形量，区域地形量，流域地形量の 計測は, 野上ほか ${ }^{17)}$ 方法に準じて行った. 各地形量の名 称や定義については太田・八戸 ${ }^{18}$ に詳しく記述されており， 本稿屯基本的には彼らの名称と定義に従う。表-3に今回計 測した地形量とその定義を示す。局所地形量は計測対象格 子点を中心とする $3 \times 3 \times ッ シ ュ(15 \mathrm{~m}$ 四方)内の格子点の 標高値を用いて算出し, 区域地形量については $5 \times 5 \times ッ$ シュ ( $25 \mathrm{~m}$ 四方) 内の格子点の標高值から求めた. 以下では, これらの局所地形量および区域地形量を流域全体ではなく 流域内の局所的な斜面の地形量を表す值という意味で「斜 面地形量」と称し, それぞれの地形量の名称の接頭語とし て「斜面」を冠することとする。調查対象地域の流域につ いては，DEMより流域面積が $0.0625 \sim 2.75 \mathrm{~km}^{2}$ の範囲にあ 表-3＼cjkstart本論文で用いた地形量とその定義

\begin{tabular}{|c|c|}
\hline 用 語 & 定 \\
\hline 斜面地形量 & 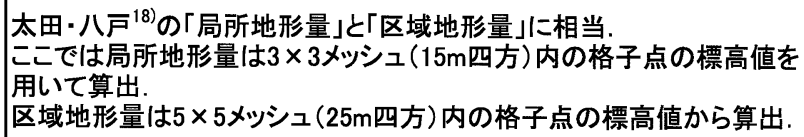 \\
\hline 斜面平均傾斜量 & $\begin{array}{l}\text { 太田·八戸 }{ }^{18)} \text { の対象格子点に隣接する4格子点の標高から算出」した } \\
\text { 「勾配·傾斜の大きさ」に相当. }\end{array}$ \\
\hline 斜面起伏量 & $\begin{array}{l}\text { 太田·八戸 }{ }^{18)} \text { の「起伏量」に相当. } \\
\text { 本報告では, } 5 \times 5 \times ッ シ ュ(25 m \text { 而)内の格子点の標高値から算出. }\end{array}$ \\
\hline 斜面高度分散量 & $\begin{array}{l}\text { 太苗·八戸 }{ }^{18)} \text { の高度分散量」に相当. } \\
\text { 本報告では, } 5 \times 5 \text { メシシュ(25m四方)内の格子点の標高值から算出. }\end{array}$ \\
\hline 斜面平均比高 & $\begin{array}{l}\text { 太田·八戸 }{ }^{18)} \text { の平均比高」に相当. } \\
\text { 本報告では, } 5 \times 5 \text { メッシュ(25m四方)内の格子点の標高値から算出. }\end{array}$ \\
\hline 流域面積 & 対象とする流域の投影面積 ${ }^{18)}$ \\
\hline 流域表面積比 & 対象とする流域の地表面の表面積を流域面積で除した値 ${ }^{18)}$ \\
\hline 流域起伏量 & 対象とする流域内の高度差を表す量. \\
\hline 流域高度分散量 & 対象流域内における標高値の不偏標準偏差. \\
\hline 流域平均比高 & $\begin{array}{l}\text { 流域体䅣と流域面積の比あるいは流域内の格子点と流域出口点との } \\
\text { 比高の平均. }\end{array}$ \\
\hline
\end{tabular}

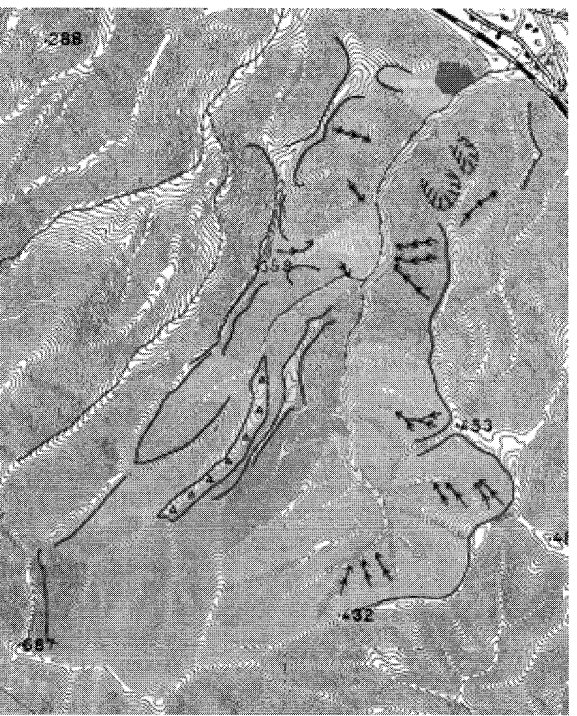

コナラ・クリ・落葉広葉樹群落 アカマツー落葉広葉樹群落 スギ植林(幼齢林) スギ植林(壮齢林) 伐採地(伐採直後) 伐採地(若齢二次林)

遷急線
崩壊地, 崩壊跡地
ガリー
崖錐堆積物
沖積錐 扇状地
段丘
採石場, 切土
砂防么, 治山堰堤
林道, 作業道

図-4 写真判読結果から作成する植生および地形の分布図

表-4 判読に用いた空中写真

\begin{tabular}{ccc}
\hline 撮影年月日 & 撮影機関 & 縮尺 \\
\hline \hline 1970年5月 & 林野庁 & $1 / 20,000$ \\
1977年10月 & 国土地理院 & $1 / 15,000$ \\
1985年5月 & 林野庁 & $1 / 16,000$ \\
1990年5月 & 林野庁 & $1 / 16,000$ \\
1995年5月 & 林野庁 & $1 / 16,000$ \\
2001年5月 & 岩手県 & $1 / 10,000$ \\
\hline
\end{tabular}

る流域を野上ほか ${ }^{17)}$ の方法に従って自動的に抽出した。抽 出する流域の設定面積は, 地形図の読図による流域の抽出 と類似するように複数回の自動抽出の試行錯誤によって決 定した。抽出されたのは図-1に示した16渓流であり，これ らの流域について流域地形量の計測を行った。地形図上で は図-1に示したKR-2とKR-3の間に屯流域が認められる が, 今回の自動抽出では刈屋川沿いの沖積低地面で流路が 迷走し, 流域として抽出されなかった。このため, この領 
域については地形計測ができなかったので, 以降の検討対 象から除外した。

\section{2 空中写真判読}

調査対象地域の植生状況や地形の経年変化を把握するた めに，1970〜2001年の間の 6 時期に撮影された空中写真 (表-4)を用いて植生および地形についての判読を行った。 各時期の写真の判読結果から植生および地形の分布図(図4)を作成し, 変化状況を把握した. 判読項目は以下のとお りである。

(1)土砂災害地形：崩壊地(発生時期を問わない), ガリーお よびガリー浸食の著しい渓流区間, 渓床堆積物など

(2)地形条件 : 遷急線，地すべり地形，段丘，崖錐，沖積錐， 扇状地など

(3)植生状況：種類, 繁茂の程度, 同一植生の分布範囲など
(4)人工改変状況: 道路(林道など), 作業道, 採石場, 切土, 伐採および植林，砂防ダムおよび治山堰堤など

これらの判読項目については，表-4に示した空中写真の 縮尺で判読可能な大きさを有するすのを読み取った。

\section{3 現地踏查}

上記の空中写真の判読から得られた土砂災害地形や地形 条件, 植生状況, 人工改変状況および空中写真では判読が 困難な微地形と植生について，現地踏査を行い確認した。

\section{4. 現地形条件が土砂災害地形の発生に及ぼす影響}

4.1 対象流域の北部北上山地における地形的位置づけ

3.1 で抽出された検討対象の16流域について，DEMを用 いた地形計測結果から得られた代表的な流域地形量を表-5 に示す.また，図-5に航空レーザ測量を行った範囲で抽出

表-5 検討対象 16 流域の代表的な地形量の值

\begin{tabular}{|c|c|c|c|c|c|c|c|c|c|c|c|c|c|}
\hline \multirow[b]{2}{*}{$\begin{array}{l}\text { 流域 } \\
\text { 番号 }\end{array}$} & \multirow[b]{2}{*}{$\begin{array}{c}\text { 平均標高 } \\
(\mathrm{m})\end{array}$} & \multicolumn{4}{|c|}{ 斜面地形量の流琙平均 } & \multicolumn{5}{|c|}{ 流琙地形量 } & \multicolumn{3}{|c|}{ 災害地形分布状況 } \\
\hline & & $\begin{array}{l}\text { 斜面平均 } \\
\text { 傾斜量の } \\
\text { 平均 }\left(^{\circ}\right)\end{array}$ & $\begin{array}{c}\text { 斜面起伏 } \\
\text { 量の平均 } \\
\text { (m) }\end{array}$ & $\begin{array}{c}\text { 斜面高度 } \\
\text { 分散量の } \\
\text { 平均 (m) }\end{array}$ & $\begin{array}{c}\text { 斜面平均 } \\
\text { 比高の } \\
\text { 平均 (m) }\end{array}$ & $\begin{array}{c}\text { 流域面積 } \\
\left(\mathrm{km}^{2}\right)\end{array}$ & $\begin{array}{c}\text { 流域 } \\
\text { 表面積比 }\end{array}$ & $\begin{array}{c}\text { 流域 } \\
\text { 起伏量 } \\
(\mathrm{m})\end{array}$ & $\begin{array}{c}\text { 流域高度 } \\
\text { 分散量 } \\
(\mathrm{m})\end{array}$ & $\begin{array}{c}\text { 流域 } \\
\text { 平均比高 } \\
(\mathrm{m})\end{array}$ & $\begin{array}{c}\text { ガリ一長 } \\
(\mathrm{km})\end{array}$ & $\begin{array}{c}\text { 崩壊箇所 } \\
\text { 数 }\end{array}$ & $\begin{array}{c}\text { 渓床 } \\
\text { 堆積物 } \\
\text { 分布面積 } \\
\left(\mathrm{km}^{2}\right)\end{array}$ \\
\hline$\overline{\mathrm{HL}-1}$ & 335.3 & 36.54 & 19.07 & $\overline{5.43}$ & 9.53 & 1.82 & 2.70 & 578.0 & 109.8 & 268.1 & 1.4 & 18 & 0.128 \\
\hline $\mathrm{HL}-2$ & 268.3 & 37.61 & 19.80 & 5.63 & 9.92 & 0.64 & 2.93 & 387.2 & 82.2 & 204.3 & 3.3 & 3 & 0.017 \\
\hline $\mathrm{KL}-1$ & 329.2 & 36.00 & 18.76 & 5.31 & 9.40 & 0.74 & 2.78 & 492.6 & 108.5 & 267.3 & 0.7 & 4 & 0.033 \\
\hline $\mathrm{KL}-2$ & 279.5 & 37.62 & 19.91 & 5.61 & 9.98 & 0.35 & 3.04 & 457.1 & 99.5 & 221.2 & 0.5 & 6 & 0.023 \\
\hline $\mathrm{KL}-3$ & 179.4 & 34.48 & 17.70 & 5.05 & 8.93 & 0.08 & 2.48 & 246.0 & 58.3 & 122.7 & 0.1 & 0 & 0.000 \\
\hline $\mathrm{KL}-4$ & 211.8 & 35.31 & 18.38 & 5.21 & 9.23 & 0.15 & 2.71 & 320.4 & 76.8 & 156.7 & 0.7 & 2 & 0.000 \\
\hline $\mathrm{KL}-5$ & 167.5 & 31.45 & 15.97 & 4.60 & 8.03 & 0.10 & 2.55 & 256.7 & 69.2 & 113.6 & 0.5 & 0 & 0.000 \\
\hline $\mathrm{KL}-6$ & 138.2 & 25.44 & 12.64 & 3.53 & 6.32 & 0.06 & 1.76 & 205.7 & 59.3 & 86.2 & 0.6 & 0 & 0.000 \\
\hline $\mathrm{KR}-1$ & 358.7 & 37.14 & 19.60 & 5.57 & 9.83 & 1.27 & 2.93 & 606.1 & 130.3 & 279.0 & 1.7 & 16 & 0.036 \\
\hline $\mathrm{KR}-2$ & 307.8 & 35.36 & 18.25 & 5.20 & 9.16 & 0.24 & 2.56 & 382.9 & 84.0 & 230.6 & 0.4 & 0 & 0.003 \\
\hline $\mathrm{KR}-3$ & 291.2 & 34.68 & 18.25 & 5.07 & 8.95 & 0.38 & 2.16 & 417.4 & 97.0 & 226.1 & 0.5 & 5 & 0.016 \\
\hline KR-4 & 216.4 & 33.66 & 17.57 & 4.90 & 8.84 & 0.12 & 2.38 & 284.4 & 62.3 & 151.5 & 0.2 & 5 & 0.003 \\
\hline KR-5 & 142.3 & 28.08 & 14.05 & 4.00 & 7.08 & 0.07 & 2.20 & 162.7 & 43.5 & 79.8 & 0.0 & 0 & 0.000 \\
\hline KR-6 & 275.3 & 35.29 & 18.24 & 5.16 & 9.15 & 0.62 & 2.25 & 407.0 & 97.3 & 207.6 & 1.7 & 13 & 0.023 \\
\hline $\mathrm{KR}-7$ & 284.1 & 33.70 & 17.08 & 4.90 & 8.61 & 0.42 & 2.04 & 406.2 & 92.3 & 227.2 & 1.3 & 2 & 0.003 \\
\hline KR-8 & 258.9 & 34.04 & 17.58 & 4.96 & 8.86 & 0.41 & 2.22 & 386.8 & 87.9 & 204.8 & 0.6 & 5 & 0.000 \\
\hline
\end{tabular}
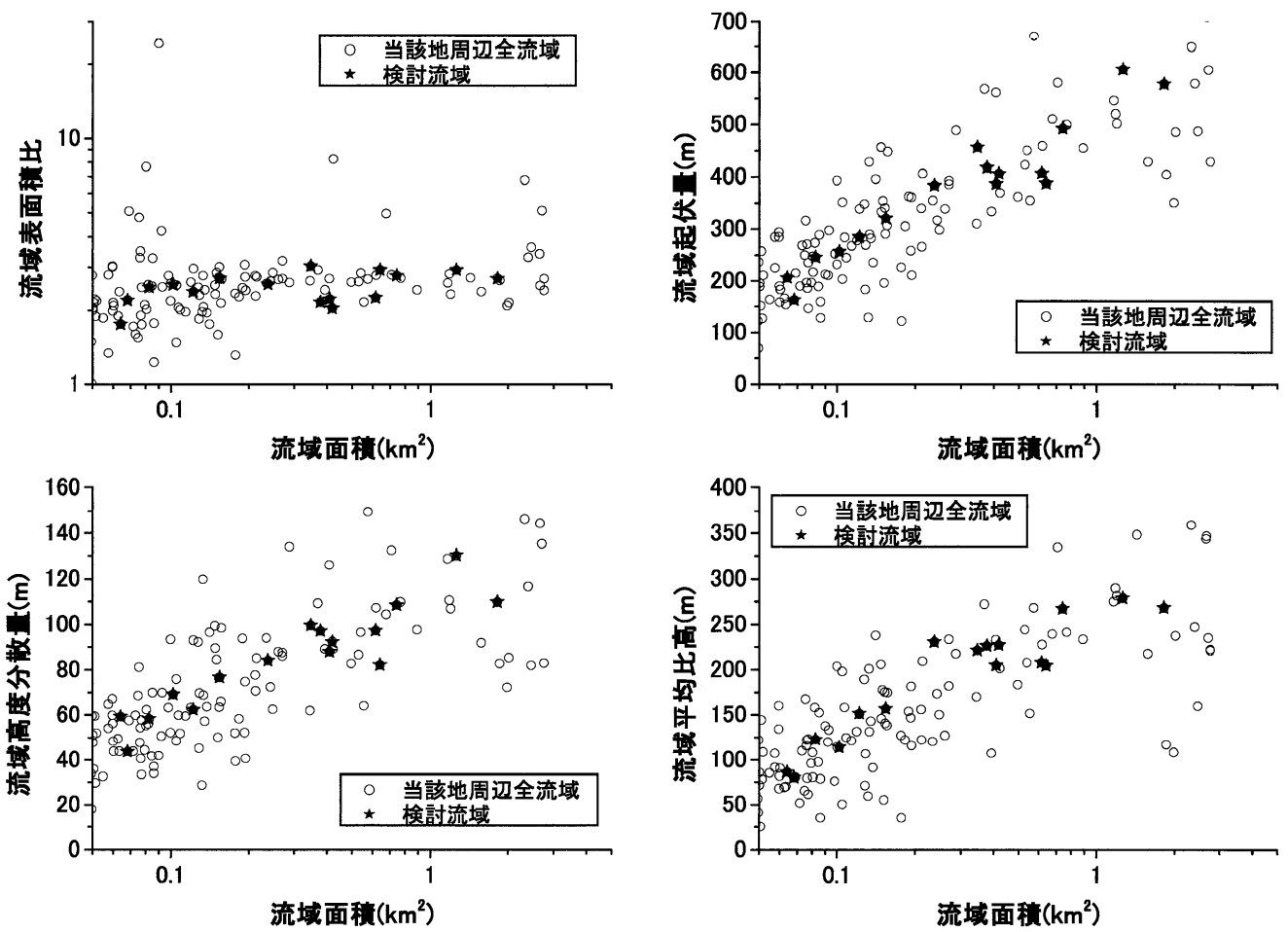

図-5 刈屋川支流の流域面積と流域地形量 
された刚屋川の支流となる全76流域と検討対象16流域の流 域面積と流域地形量の関係を示した。

検討対象範囲で抽出された 16 流域は流域面積が 0.06 $1.82 \mathrm{~km}^{2}$ であり, 流域表面積比は1.76〜3.04の範囲にある (表-5). 流域高度分散量および流域平均比高はそれぞれ 43.5〜 130.3m，79.8〜279.0mの範囲にある.これらの流域 は, 対象地周辺の刚屋川支流である他流域と比較すると, 流域面積 $0.05 \mathrm{~km}^{2}$ 以上の流域の中では, 平均的な地形の特 徵を有するといえる(図-5). 大局的に見ると, 当該地周辺 の流域では流域起伏量, 流域高度分散量, 流域平均比高は 流域面積之相関がみられ, 検討対象渓流屯同様の特徵があ る.これらのことから, 検討対象の16流域は北部北上山地 東部の刚屋川流域において特異な地形を示す流域ではなく， 刚屋川流域における地形発達過程のシステム内にあると考 えることができる.

\section{2 地形量亡土砂災害地形分布の関係}

次に，用いた $5 \mathrm{~m}-\mathrm{DEM}$ は2000年に作成したデータであ るので，地形条件が土砂災害地形の発生に及ぼす影響を検 討するために，2001年の判読結果による土砂災害地形の分 布状況とDEMから求めた地形量の分布との関係を検討し た。

まず，流域全体の地形の特徵と土砂災害地形の分布状況 を検討する。図-6に各流域における流域表面積比, 流域起
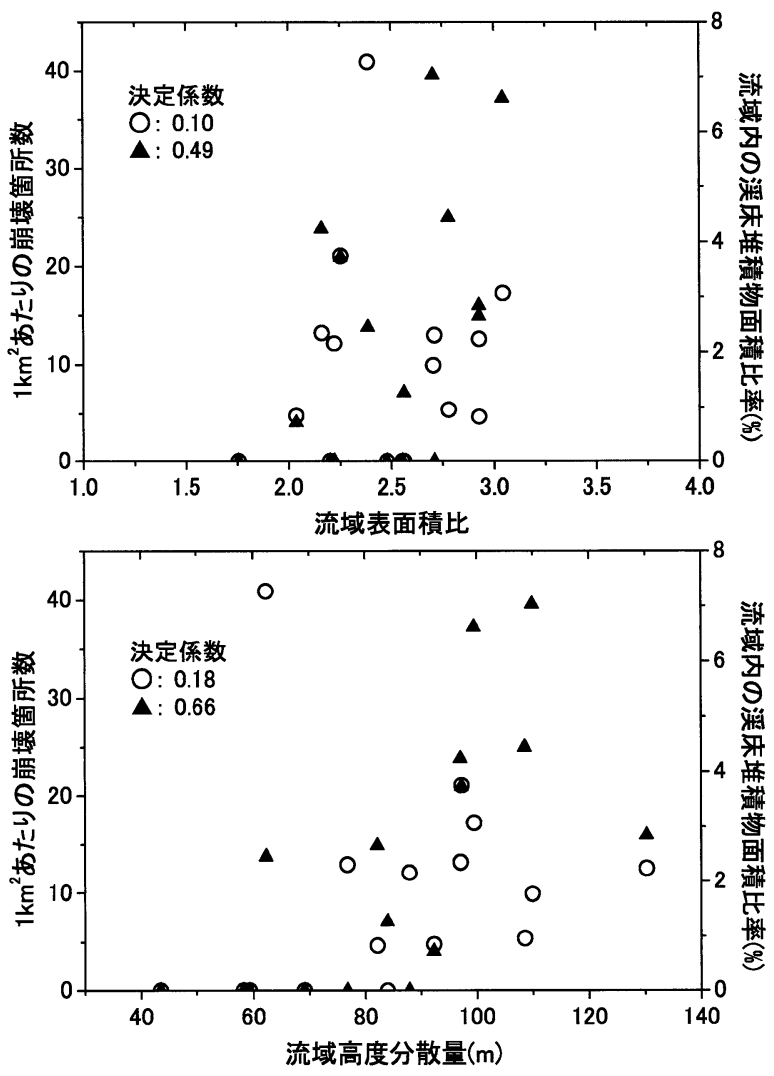

伏量, 流域平均比高および流域高度分散量に対する $1 \mathrm{~km}^{2}$ あたりの崩壊箇所数および流域内の渓床堆積物面積比率を 示す。この四つの地形量はいずれす地形が険しくなる，あ るいは凹凸が大きくなると大きな値となる地形量であるの で, これらの地形量が大きな流域は地形が険しく浸食活動 あ活発であると考えられる。図一6では, 起伏に関係する指 標である流域起伏量, 流域平均比高および流域高度分散量 で崩壊箇所数・渓床堆積物面積比率との相関がわずかに見 られる程度で, 勾配に関係する指標の流域表面積比ではほ とんど関係が見られない。

次に, 各流域における斜面地形量の流域平均值と $1 \mathrm{~km}^{2}$ あたりの崩壊箇所数および流域内の渓床堆積物面積比率と の関係を図-7に示す. 図に示すいずれの斜面地形量の平均 值においても崩壊地や渓床堆積物の分布が確認されない流 域で小さい值を示す. また崩壊地や渓床堆積物が認められ る流域については, これらの斜面地形量の流域平均は崩壊 箇所数や渓床堆積物分布比率と弱いながらあ正の相関を示 す.

図-6,7には, 各地形量と崩壊箇所数および渓床堆積物分 布比率之の間の決定係数 $(R)$ を付記した。決定係数では, 流域地形量も斜面地形量の流域平均值屯土砂災害地形の分 布量と同程度の相関がある。しかし, 同じ地形条件でも判 読した写真が撮影された時点で必ず土砂災害地形が分布し
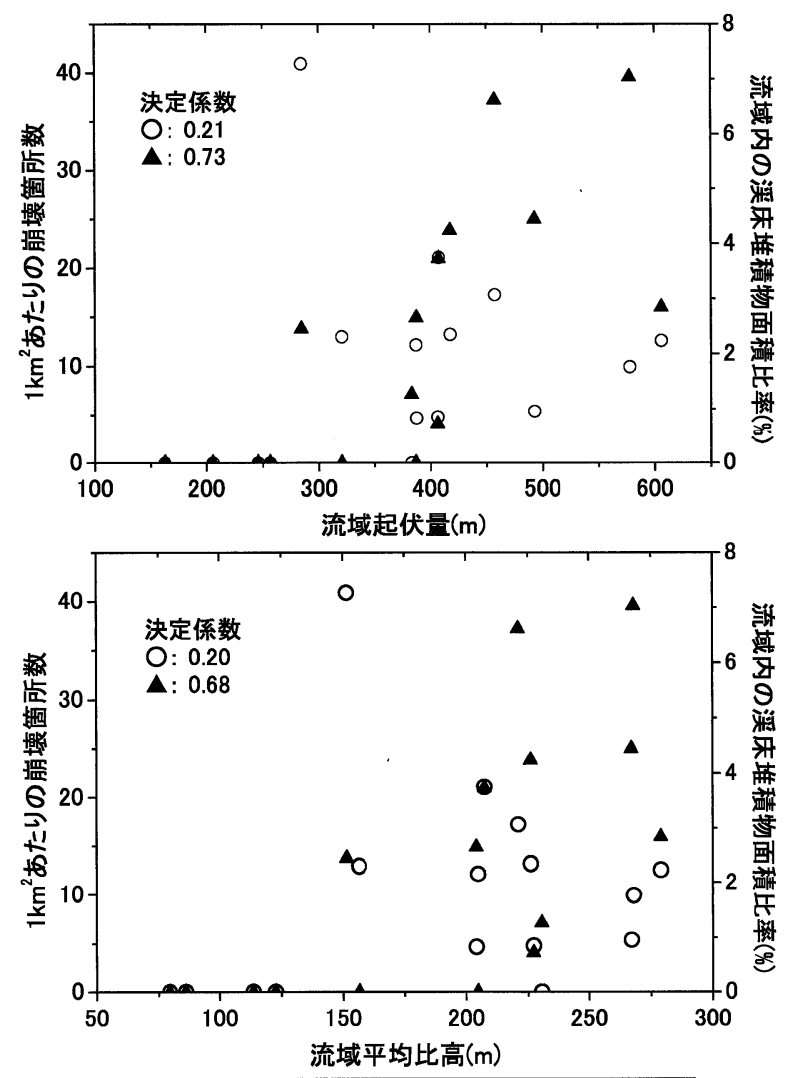

$1 \mathrm{~km}^{2}$ あたりの崩壊箇所数

流域内の渓床堆積物面積比率 

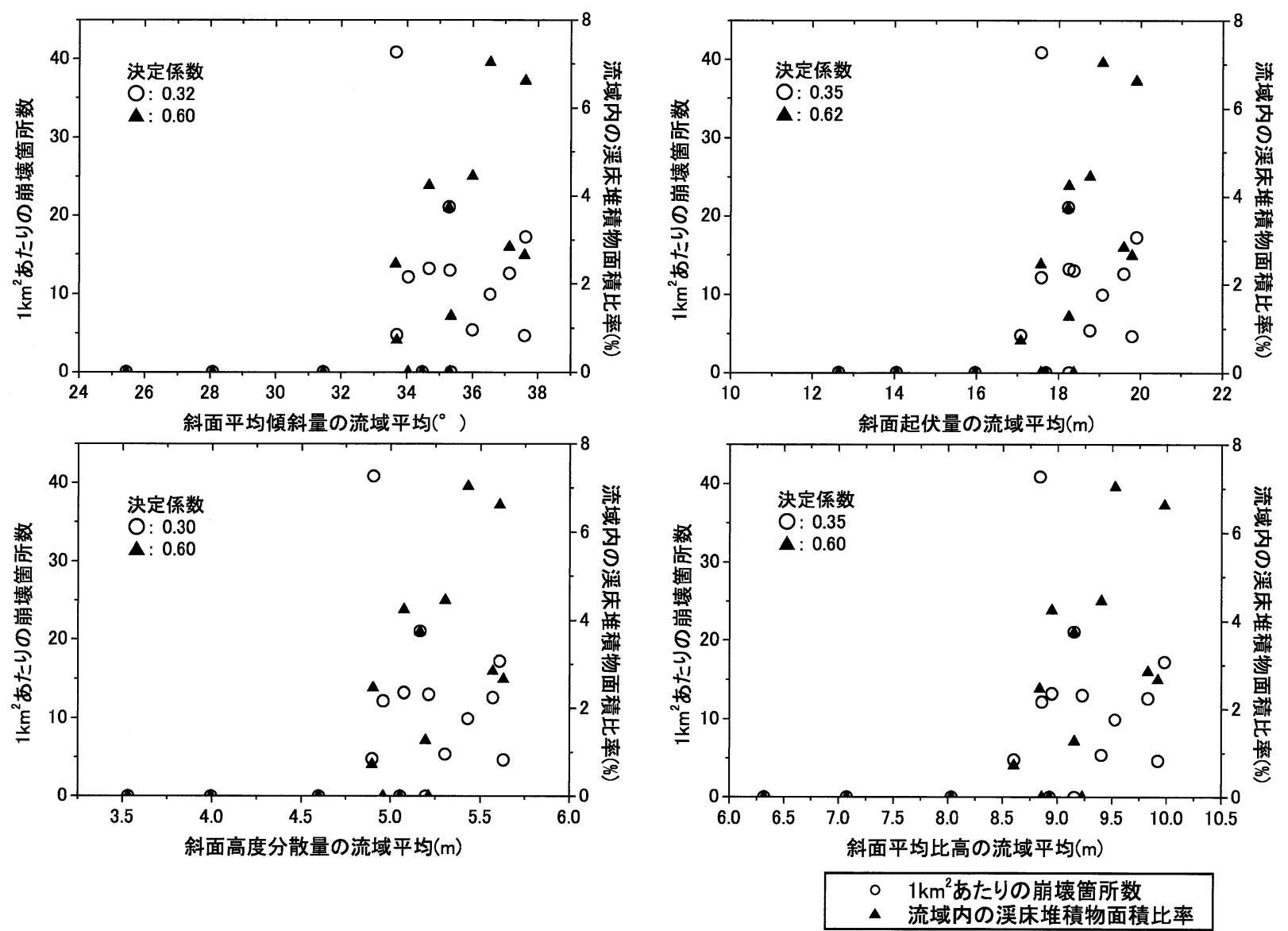

図-7 検討対象 16 流域における斜面地形量の流域平均值と土砂災害地形分布量の関係

ていたとは限らないので, 図-6,7の散布図における上限值 に意味があると考えられる。図-7の斜面地形量の流域平均 值と土砂災害地形の分布量との関係の方が，図-6の流域地 形量の場合よりも，上限值に近い所に各渓流の值が分布し ている，このことから，流域内の崩壊現象や崩壊物質の堆 積は流域全体の地形的な特徵ではなく，流域に分布するそ れぞれの斜面の局所的な地形条件に左右される可能性が考 えられる。

\section{5. 植生変化が土砂災害地形の発生に及ぼす影響}

\section{1 空中写真判読による植生変化の状況把握}

表-6に16流域の各時期における空中写真判読結果と各時 期の間での植生变化および地形变化の特徵を示す。空中写 真判読では詳細な植生区分が困難であったため，広葉樹は コナラ・クリ・落葉広葉樹群落あるいは伐採後の若齢二次 林に区分し，スギおよびヒノキなど植林された針葉樹はス ギ植林の幼齢林またはスギ植林の壮齢林として区分した. 針葉樹のうちアカマッは他の針葉樹から区別可能であった ので, アカマツ・落葉広葉樹群落として区分した．この群 落は分布が尾根に限られているので, 表-6中の植生状況で は省略した。

図-8に植生変化の例として，流域KR-1の各時期の空中 写真による判読結果を示す。1970年には流域の広い範囲が
伐採後の二次林で占められており，1960年代に広く伐採が 行われていたことがうかがえる，1977年には南東向き斜面 の伐採後二次林がコナラ・クリ・落葉広葉樹群落に成長し, 1985年では流域のほぼ全域で植生が回復している。1990年 以降，再度の伐採とスギなどの植林が実施され，2001年に は流域上流部がスギ幼齢林，下流部が伐採後二次林で占め られる。

\section{2 植生変化之土砂災害地形の分布状況の関係}

表-6に示すように，1995～2001年の間に16流域中 9 流域 で判読できたガリ一延長の増大や崩壊箇所数の増加が認め られる。このような土砂災害地形の分布量が増加した流域 では，この期間あるいはそれ以前にコナラ・クリ・落葉広 葉樹群落が伐採により減少し, 伐採箇所の植生が2001年で は若齢二次林やスギの幼齢林などで, 十分植生が回復して いない状態にある(表-6). そこで, 検討対象の16流域につ いて, 流域を占める植生の比率之土砂災害地形の分布量の 関係を経時的に検討した，その結果，植生状況の変化と土 砂災害地形の分布量の変化から, 対象とした16流域は表-7 に示す五つに区分できることがわかった。

それぞれのグループの代表的な流域について，各植生の 占有率および土砂災害地形の分布量の経時变化を図-9に示 す. 各グループの植生変化および土砂災害地形分布の変化 に関する特徴は以下のとおりである。 
表-6 検討対象16流域における植生変化および地形変化の空中写真判読結果

\begin{tabular}{|c|c|c|c|c|c|c|c|}
\hline & 撮影年 & 1970 & 1977 & 1985 & 1990 & 1995 & 2001 \\
\hline \multirow{3}{*}{$\mathrm{HL}-1$} & 植生状況 & $\begin{array}{l}\mathrm{BF}, \mathrm{SS}, \\
\text { 一部CC, CF }\end{array}$ & $\begin{array}{l}\text { 大部分BF, } \\
\text { 一部CF }\end{array}$ & 一部CF, CC & $\begin{array}{l}B F, C C, \\
\text { - 部CF }\end{array}$ & 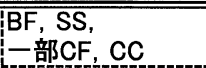 & $\begin{array}{l}\mathrm{BF}, \mathrm{SS}, \\
\text { 一部CF }\end{array}$ \\
\hline & 妿门二延長 $(\mathrm{km})$ & 1.47 & 1.48 & 1.02 & 1.02 & 1.02 & 1.42 \\
\hline & 崩壊箇所数 & 11 & 9 & 14 & 28 & 9 & 18 \\
\hline \multirow[t]{3}{*}{$\mathrm{HL}-2$} & 植生状況 & $\begin{array}{l}\text { 大部分BF, } \\
\text { 一部CC }\end{array}$ & $\begin{array}{l}\text { BF(アカマツ多), } \\
\text { ごく一部CF }\end{array}$ & $\begin{array}{l}\text { BF(アカマツ多)， } \\
\text { ごくー部CF }\end{array}$ & $\begin{array}{l}\mathrm{BF} \text { (アカマツ多)， } \\
\text { 二部CC, } \\
\text { ごく一部CF }\end{array}$ & $\begin{array}{l}\text { BF(アカマツ多), } \\
\text { 一部SS, } \\
\text { ごく一部CF }\end{array}$ & $\begin{array}{l}\mathrm{BF} \text { (アカマツ多), } \\
\text { 二部SS, } \\
\text { こくく-部CF }\end{array}$ \\
\hline & 於二延長 $(\mathrm{km})$ & 3.52 & 3.01 & 3.01 & 3.01 & 3.01 & 331 \\
\hline & 崩壊箇所数 & 4 & 3 & 4 & 3 & 3 & 3 \\
\hline \multirow{3}{*}{$\mathrm{KL}-1$} & 植生状況 & BF, CC, CY & 全域BF & BF, & $\mathrm{BF}, \mathrm{CC}, \mathrm{CF}$ & BF, CY, CF & $\mathrm{BF}, \mathrm{CY}$ \\
\hline & 分门二延長 $(\mathrm{km})$ & 1.05 & 0.55 & 0.55 & 0.55 & 0.55 & 0.74 \\
\hline & 朤壊箇耎数 & 4 & 6 & 3 & 3 & 3 & 4 \\
\hline \multirow{3}{*}{$\mathrm{KL}-2$} & 植生状況 & $\begin{array}{l}B F, C C, \\
\text { - 部CF }\end{array}$ & 一F, & BF, CF & $\mathrm{BF}, \mathrm{CF}$ & BF, CF & $\begin{array}{l}\mathrm{BF}, \mathrm{CF}, \\
\text { - 部SS }\end{array}$ \\
\hline & 辽二延長(km) & 0.45 & 045 & 0.45 & 0.45 & 0.45 & 0.45 \\
\hline & 崩壊箇所数 & 2 & 3 & 2 & 2 & 2 & 6 \\
\hline \multirow{3}{*}{$\mathrm{KL}-3$} & 植生状況 & $\mathrm{BF}, \mathrm{CC}$ & $\begin{array}{l}\text { 大部分BF, } \\
\text { 部SS }\end{array}$ & 全域BF & 全域BF & 全域BF & BF, CF \\
\hline & 妿 & 0.10 & 0.10 & 0.10 & 0.10 & 0.10 & 0.10 \\
\hline & 崩壊箇所数 & 0 & 0 & 0 & 0 & 0 & 0 \\
\hline \multirow{3}{*}{$\mathrm{KL}-4$} & 植生状況 & $B F, C C$ & BF, SS & 全域BF & 全域BF & 全域BF & $\begin{array}{l}\mathrm{BF}, \\
\text { 一部渓流沿いCF }\end{array}$ \\
\hline & 妿行延長 $(\mathrm{km})$ & 0.65 & 0.65 & 0.65 & 0.65 & 0.65 & - 65 \\
\hline & 崩壊管所数 & 2 & 2 & 2 & 2 & 2 & 2 \\
\hline \multirow{3}{*}{$\mathrm{KL}-5$} & 植生状況 & 太部分BF & 全域BF & 全域BF & 全域BF & 全域BF & CF, BF \\
\hline & 方门一延長 $(\mathrm{km})$ & 0.50 & 0.50 & 0.50 & 0.50 & 0.50 & 0.50 \\
\hline & 崩壊箇折数 & 0 & 2 & 0 & 0 & 0 & 0 \\
\hline \multirow[t]{3}{*}{$\mathrm{KL}-6$} & 植生状況 & $\mathrm{BF}, \mathrm{CC}$ & $\begin{array}{l}\text { 全域BF(大部分 } \\
\text { はコナラ類からア } \\
\text { 力マほに) }\end{array}$ & 全域BF & 全域BF & 全域BF & 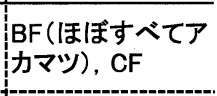 \\
\hline & 妿仁延長 $(\mathrm{km})$ & 0.56 & 0.56 & 0.56 & 0.56 & 0.56 & 0.56 \\
\hline & 算壊箇所数 & 0 & 0 & 0 & 0 & 0 & 0 \\
\hline \multirow{3}{*}{$\mathrm{KR}-1$} & 植生状況 & $\begin{array}{l}\mathrm{SS}, \mathrm{BF}, \\
\text { - 部CC}\end{array}$ & BF, & $\begin{array}{l}B F, \\
\text { Ċく-部CC }\end{array}$ & $\begin{array}{l}B F, C C, \\
\text { - 部CY }\end{array}$ & $\begin{array}{l}\mathrm{CY}, \mathrm{BF}, \mathrm{CC}, \\
\text { - 部S }\end{array}$ & $\begin{array}{l}\mathrm{CY}, \mathrm{SS}, \\
\text { 一部BF }\end{array}$ \\
\hline & 吕门二延長 $(\mathrm{km})$ & 3.47 & 1.57 & 1.57 & 1.57 & 1.78 & 1.67 \\
\hline & 崩壊箇所数 & 7 & 4 & 4 & 4 & 14 & 16 \\
\hline \multirow{3}{*}{$\mathrm{KR}-2$} & 植生状況 & BF, $\mathrm{CY}, \mathrm{CC}$ & BF, CY & $\mathrm{BF}, \mathrm{CF}, \mathrm{CC}$ & BF, CF & $\mathrm{BF}, \mathrm{CF}$ & BF, \\
\hline & 穷少一庭 $(\mathrm{km})$ & 0.56 & 0.40 & 0.40 & 0.43 & 0.40 & 0.43 \\
\hline & 崩壊箇所数 & 0 & 0 & 2 & 0 & 0 & 0 \\
\hline \multirow{3}{*}{$\mathrm{KR}-3$} & 植生状況 & $\begin{array}{l}B F \text { 主体, } \\
\text { 二部CC, CY, CF }\end{array}$ & BF, CY & BF, CY & $\mathrm{BF}, \mathrm{CF}$ & $\mathrm{CC}, \mathrm{BF}, \mathrm{CF}$ & SS, BF, CF \\
\hline & 书延長(km) & 0.63 & 0.59 & 0.54 & 0.54 & 0.54 & 0.54 \\
\hline & 崩壊䓢所数 & 1 & 0 & 1 & 0 & 0 & 5 \\
\hline \multirow{3}{*}{$\mathrm{KR}-4$} & 植生状況 & 全域BF & 全域BF & 全域BF & 全域BF & 全域BF & CC, \\
\hline & 殁门二延長 $(\mathrm{km})$ & 0.07 & 0.07 & 0.07 & 0.07 & 0.07 & 0.17 \\
\hline & 崩壊䈯所数 & 2 & 2 & 2 & 2 & 2 & 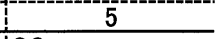 \\
\hline \multirow{3}{*}{ KR-5 } & 植生状況 & BF, & - & 二部CF & BF, & CC, & CC, \\
\hline & 过-延長 $(\mathrm{km})$ & 0.03 & 0.03 & 0.03 & 0.03 & 0.03 & 0.03 \\
\hline & 筋壊箇所数 & 0 & 0 & 0 & 0 & 0 & 0 \\
\hline \multirow{3}{*}{$\mathrm{KR}-6$} & 植生状況 & 二部 $C F, C C$ & $\begin{array}{l}\mathrm{BF}, \\
\text { - 部CY }\end{array}$ & BF, & $\begin{array}{l}B F, \\
\text {-部CF }\end{array}$ & BF, & $\begin{array}{l}\mathrm{CC}, \\
\text { - } \mathrm{s} B \mathrm{~B}, \mathrm{CF}\end{array}$ \\
\hline & 穷门二延長 $(\mathrm{km})$ & 214 & 1.54 & 1.54 & 1.54 & 1.54 & 1.71 \\
\hline & 崩壊箇所数 & 5 & 3 & 3 & 3 & 3 & 13 \\
\hline \multirow{3}{*}{$\mathrm{KR}-7$} & 植生状況 & $\begin{array}{l}\mathrm{BF}, \mathrm{CC}, \\
\text { - 部CF }\end{array}$ & $\mathrm{BF}, \mathrm{CF}, \mathrm{CY}$ & BF, CF, CY & $\mathrm{BF}, \mathrm{CF}$ & BF, CF & 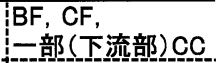 \\
\hline & 边二延長 $(\mathrm{km})$ & 1.29 & 1.29 & 1.29 & 1.29 & 1.29 & 1.29 \\
\hline & 崩壊箇所数 & 2 & 2 & 2 & 2 & 2 & 2 \\
\hline \multirow{3}{*}{ KR-8 } & 植生状況 & BF主体, CC & $\begin{array}{l}B F, C Y, \\
\text { C゙く一部CF }\end{array}$ & $\begin{array}{l}\mathrm{BF}, \mathrm{CY}, \\
\text { Cこく-部CF }\end{array}$ & BF, CF & $\mathrm{BF}, \mathrm{CF}$ & $\mathrm{CC}, \mathrm{CF}, \mathrm{BF}$ \\
\hline & 空门二延長 $(\mathrm{km})$ & 0.55 & 1.16 & 0.64 & 0.55 & 0.55 & 0.55 \\
\hline & 崩壊䓢所数 & 5 & 7 & 5 & 5 & 5 & 5 \\
\hline
\end{tabular}

凡例

植生状況 BF:コナラ·クリ·落葉広葉樹群落, CF:スギ植林(荘齢林), CY:スギ植林(幼齢林), CC:伐採跡地, SS:若齢二次林

グループI ：1970年から2001年にかけて植生がコナラ・ク

リ・葉樹群落に回復するのにともない, 土砂災害地形は減 少し，伐採開始後に増加する.

グループIII : 植生の変化はほとんど見られないが，土砂災 害地形の分布量が大きく変動する.

グループIII：1990年以降に広範囲で伐採が行われているが, 土砂災害地形の増加など变化は認められない.
グループIV：1990年以降に伐採が行われ，それにともなっ て1995年以降に土砂災害地形の分布量が増加する. 流域 KR-7はガリー延長や崩壊箇所数の変化はないが，2001年 に伐採跡地内の流路で渓床堆積物が増加したため,このグ ループに分類した。

グループ V : 植生分布に大きな変化はなく, 土砂災害地形 の分布量にも変化がない. 

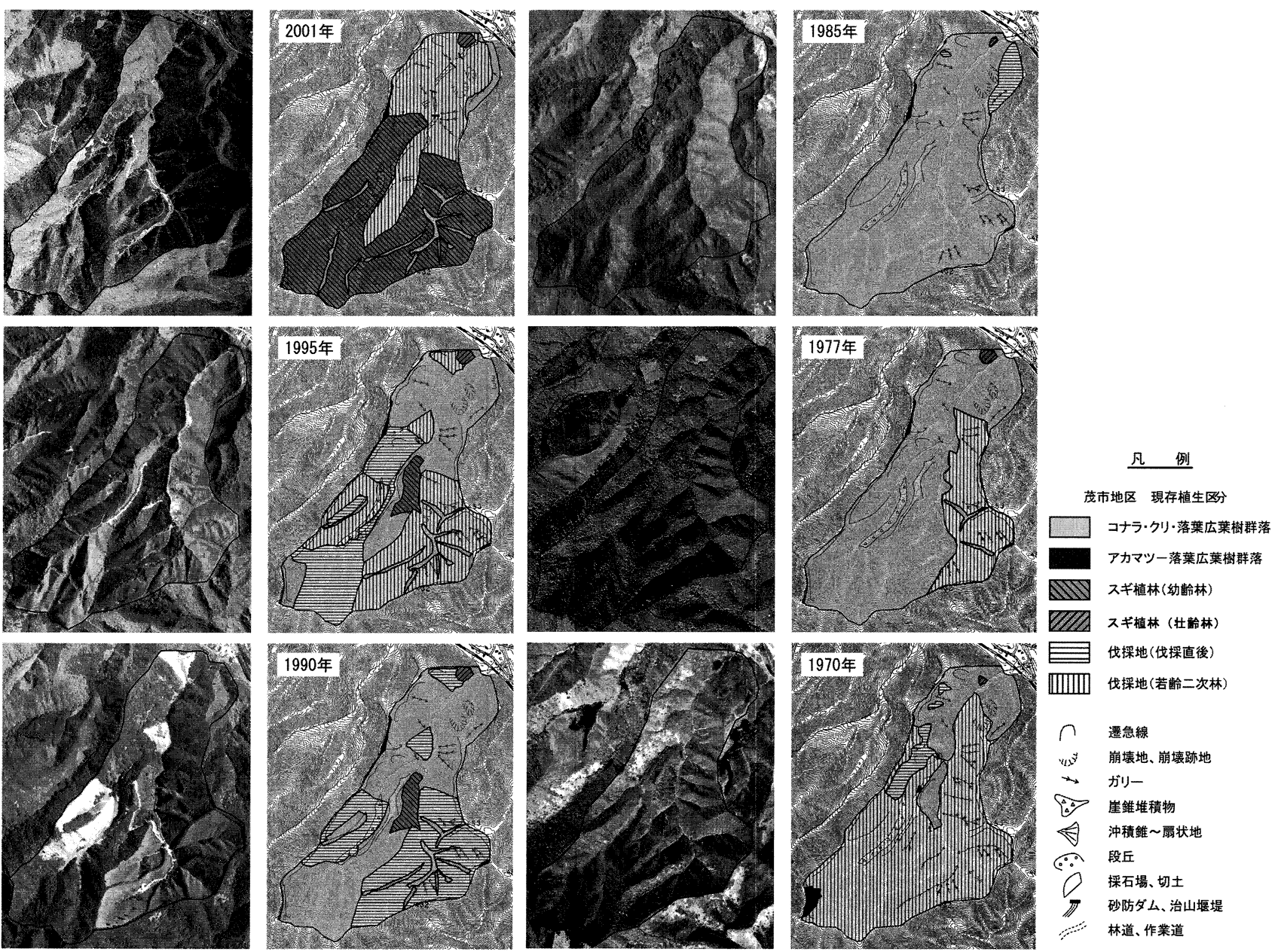

図-8 流域KR-1 の各時期の判読結果

表-7 各流域グループの植生変化, 土砂災害地形分布, 流域の地形の特徵

\begin{tabular}{|c|c|c|c|c|}
\hline グループ & 対象流域 & 植生変化の特徵 & 土砂災害地形の分布状況 & 流域の地形的特徵 \\
\hline I & $\begin{array}{c}\mathrm{HL}-1, \mathrm{KL}-1, \\
\mathrm{KR}-1\end{array}$ & $\begin{array}{l}\text { 複数の植生区分の分布率 } \\
\text { 大きく変化 }\end{array}$ & $\begin{array}{l}\text { 植生区分の分布率変化にとも } \\
\text { なう分布数量の大な変動 }\end{array}$ & $\begin{array}{l}\text { ·流域面積大 }\left(0.7 \mathrm{~km}^{2} \text { 以上 }\right) \text { ，かつ流域表面積 } \\
\text { 比やや }(2.70-2.93) \\
\text { 斜面平均傾斜量の流域平均が } 36.0-37.14^{\circ}\end{array}$ \\
\hline II & $\mathrm{HL}-2, \mathrm{KL}-2$ & $\begin{array}{l}\text { コナラ·クリ·落葉広葉樹群 } \\
\text { 落(アカマツ・落葉広葉樹 } \\
\text { 群落含む)が } 80 \% \text { 上でほ } \\
\text { ぼ一定 }\end{array}$ & 分布数量の大きな変動 & $\begin{array}{l}\text { - 流域表面積比が大 }(2.93-3.04) \\
\text { - 斜面平均傾斜量の流域平均が } 37.6^{\circ} \text { 以上 }\end{array}$ \\
\hline III & $\begin{array}{c}\mathrm{KL}-5, \mathrm{KR}-5, \\
\mathrm{KR}-8\end{array}$ & $\begin{array}{l}\text { 1990年以降にコナラ·クリ·洛葉広葉樹群落伐採 } \\
\text { la }\end{array}$ & 分布数量ほぼ変化なし & $\begin{array}{l}\text { ·流域面積が小さい }\left(0.1 \mathrm{~km}^{2} \text { 以下), あるいは }\right. \\
\text { 流域面積が中程度 }\left(0.41 \mathrm{~km}^{2}\right) \text { の場合は流域 } \\
\text { 表面積比が小さい(2.22) }\end{array}$ \\
\hline IV & $\begin{array}{l}\text { KR-3,KR-4, } \\
\text { KR-6,KR-7 }\end{array}$ & $\begin{array}{l}\text { 1990年以降にコナラ·クリ· } \\
\text { 落葉広葉樹群落伐採 }\end{array}$ & $\begin{array}{l}\cdot 1995 \text { 年以降に分布数量が増 } \\
\text { 加 } \\
\text { ·植生変化に対する分布数量が } \\
\text { 羊れて増加 }\end{array}$ & $\begin{array}{l}\text { ·中程度の流域面積 }\left(0.38-0.67 \mathrm{~km}^{2}\right) \text { で小さな } \\
\text { 流域表面積比 }(2.04-2.25) \text {, あるいは小さな } \\
\text { 流域面積 }\left(0.12 \mathrm{~km}^{2}\right) \text { で中程度の流域表面積 } \\
\text { 比 }(2.38) \\
\text { ·斜面平均傾斜量の流域平均が } 35.3^{\circ} \text { 以下 }\end{array}$ \\
\hline V & $\begin{array}{l}\mathrm{KL}-3, \mathrm{KL}-4 \\
\mathrm{KL}-6, \mathrm{KR}-2\end{array}$ & 変化なし & 変化な & $\begin{array}{l}\text { - 小さな流域面積 }\left(0.24 \mathrm{~km}^{2} \text { 以下) }\right. \\
\text { - 斜面平均傾斜量の流域平均が } 35.4^{\circ} \text { 以下 }\end{array}$ \\
\hline
\end{tabular}

\section{6. 考 察}

\section{1 土砂災害地形の発生と地形量および植生変化量と の関係}

図-9に示した結果抢よび前述した各渓流の地形的特徴な どから，グループごとの地形条件・植生変化と土砂災害地
形発達の関係は以下のようにまとめられる(表-7参照)。図一 10には各流域の地形的特徴をグループごとに記号を变えて 示した。

(1)グループI の 3 流域は植生の回復・伐採にと屯なう土砂 災害地形の消長が顕著である。これらの流域は，対象流域 中もっ之も流域面積の大きい流域 $\left(0.7 \mathrm{~km}^{2}\right.$ 以上) に相当し， 

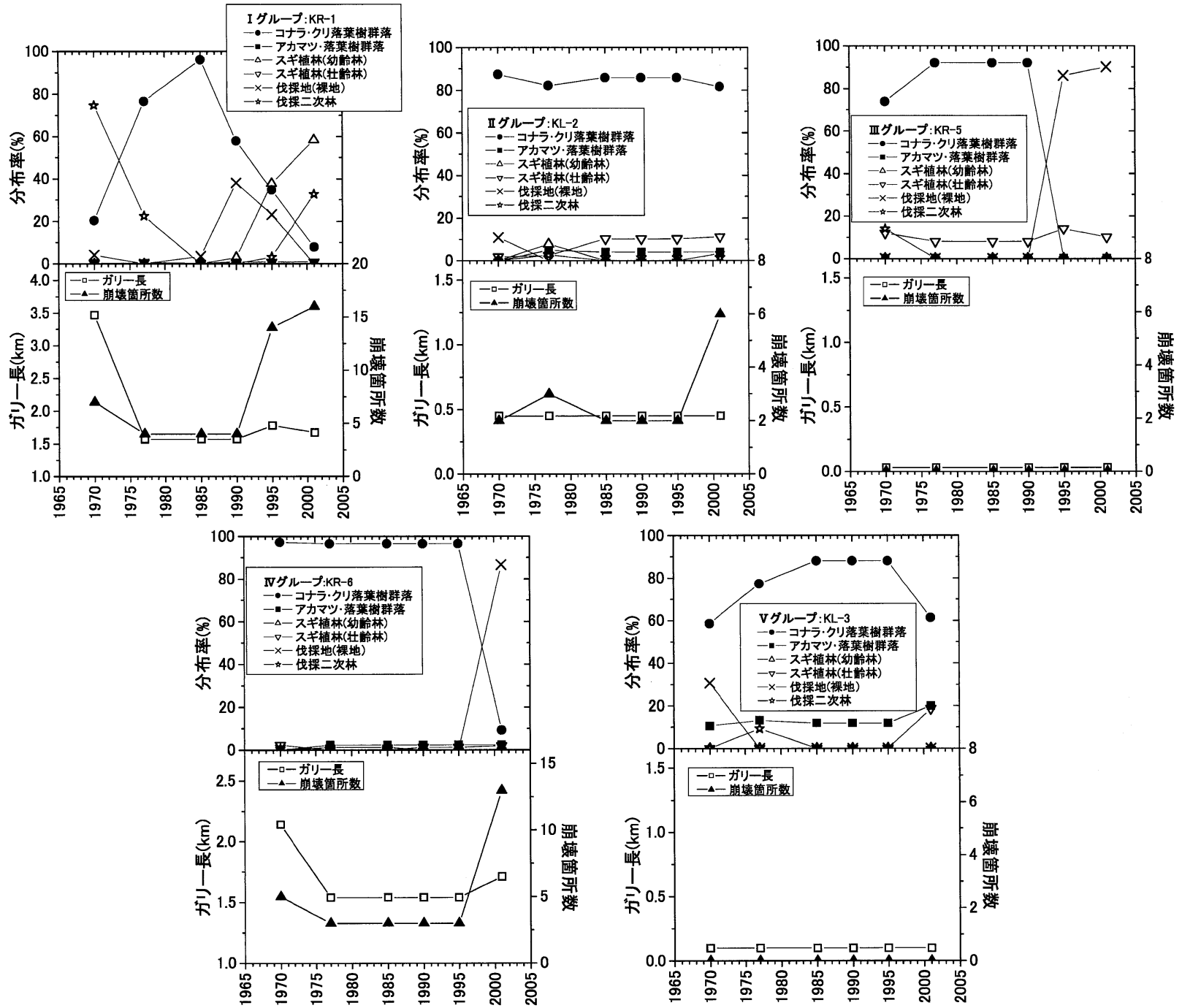

図-9 代表的な流域の植生占有率と土砂災害地形分布量の経時変化
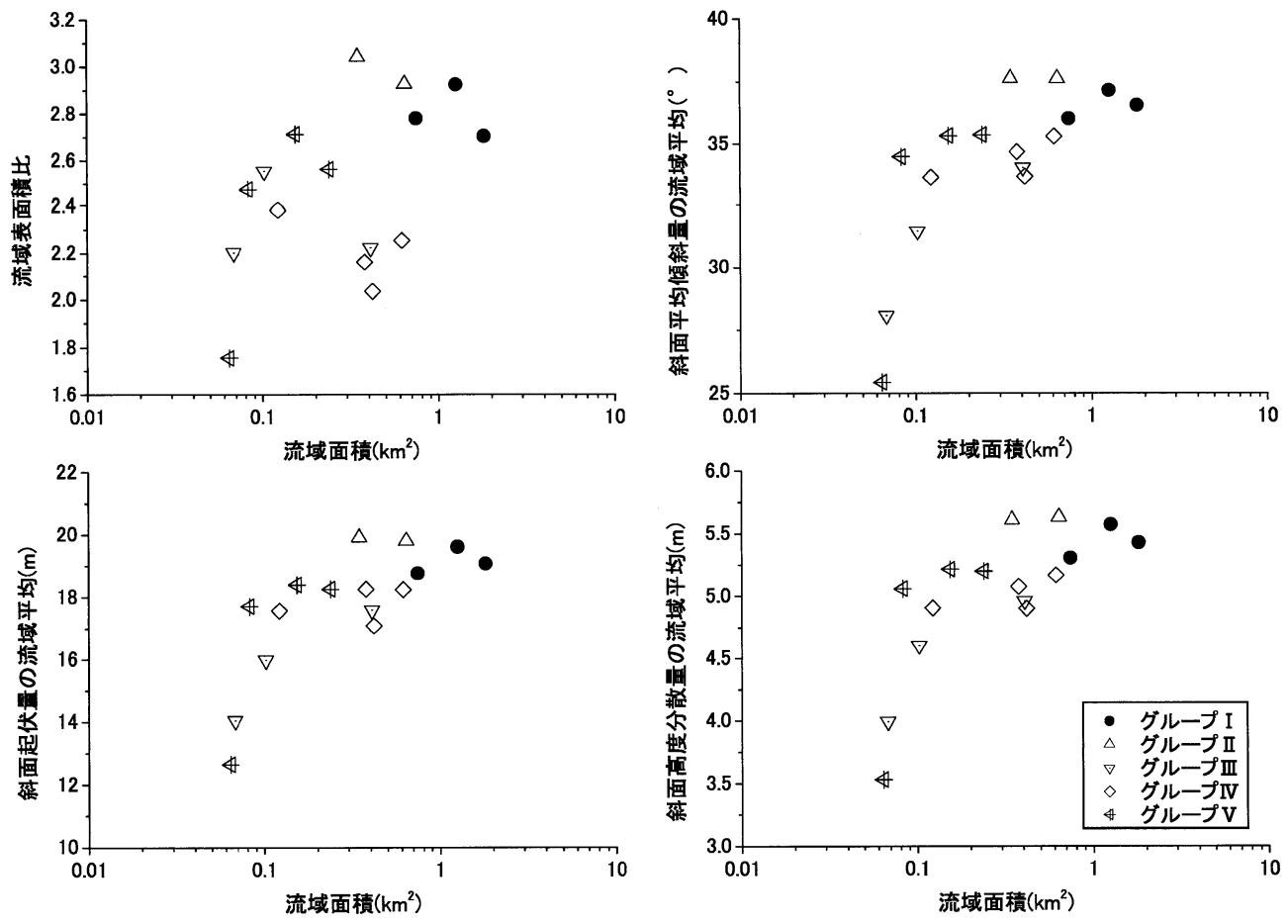

図-10 流域グループごとの地形的特徴 
表面積比(2.70 2.93), 斜面平均傾斜量の流域平均(36.0 $\left.37.14^{\circ}\right)$, 斜面高度分散量の流域平均(5.31〜 5.57m)などが 比較的大きい.

(2)植生の变化が小さいにもかかわらず土砂災害地形の変化 が顕著なグループ II は, 表面積比(2.93〜3.04)のほか斜面 平均傾斜量 ( $37.6^{\circ}$ 以上), 斜面起伏量 ( $19.8 \mathrm{~m}$ 以上), 斜面高 度分散量 (5.6m以上)など斜面地形量の流域平均值が対象 流域中むっとも大きい.

(3)グループIII は1990年以降の伐採にかかわらず土砂災害地 形の増加が見られない。これらの流域は, 流域面積が 0.1 $\mathrm{km}^{2}$ 以下と小さいか, あるいは流域面積が $0.4 \mathrm{~km}^{2}$ 程度の場 合は表面積比が 2.2 程度で他の流域に比べ小さい特徵があ る.

(4)グループIVでは1990年以降の伐採にともなって，土砂災 害地形が1995年以降に増加している。これらの流域は表面 積比が 2.4 以下を示し, とくに流域面積が $0.3 \sim 0.7 \mathrm{~km}^{2}$ では, 同程度の流域面積を示すグループ II の流域表面積比が 3.0 前後を示すのに比較して，顕著に小さい.

(5)植生, 土砂災害地形ともに変化のないグループ Vの 4 流 域は, 流域面積が $0.3 \mathrm{~km}^{2}$ 以下であるが, 他の地形的特徵 は見られない。

以上のように，今回の検討対象流域のうちグループ I, IVでは植生の変化にともなう土砂災害地形の消長が明らか に認められる．また，グループI， IIでは土砂災害地形の 発生への地形条件の関与が推定される.さらに, 土砂災害 地形の増加が認められないグループVは, 流域面積が小さ く, 植生の変化が認められない流域である.これらのこと から, 流域内の土砂災害地形の発生や増加には, 現在の地 形条件と植生の変化が影響していることが推定される.

また，グループIIIの流域では土砂災害地形の増加が認め られないが，グループIV と地形的な特徴が類似しており， かつ植生変化む1990年以降の伐採などほぼ同じ变化を示す ことから, 今後土砂災害地形の発生や増加が予想される。

\section{2 地形条件と植生条件による災害危険性評価の可能} 性

前節で述べたように, 土砂災害地形の発生や増加に現地 形の条件之植生の変化が影響すると考えられるので, 災害 発生の危険性を地形条件と植生条件の組み合わせにより評 価することが可能と思われる，そこで，例として2001年の 空中写真で判読される流域内の斜面崩壊について，2000年 作成のDEMから求められる地形条件と2001年の空中写真 から判読される植生条件から土砂災害の発生危険性につい て評価を試みる。

第 4 章で述べたように, 流域内の崩壊地の数量は流域地 形量よりあ斜面地形量の流域平均值とよい相関を示すこと から, 流域内の斜面崩壊に影響する地形因子のひとつとし て斜面平均傾斜量の流域平均值が挙げられる(図-7参照).
また，図一-9に示した植生と土砂災害地形の経時変化から， 伐採によりクリ・コナラ・落葉広葉樹群落が減少し, 伐採 裸地, 伐採後二次林およびスギ幼齢林の分布率が増加する と土砂災害地形の分布量が増加する。このことから, 斜面 崩壊の発生を促進する植生条件として伐採裸地, 伐採後二 次林およびスギ幼齢林の分布率が考えられる。図-11に 2001年時点での流域内の斜面平均傾斜量の平均值, 伐採裸 地十伐採後二次林＋スギ幼齢林の分布率および単位面積あ たりの崩壊箇所数の関係を 3 次元グラフで示す. また, 図一 12 には図-11の 3 平面へ投影したグラフを示す。これらの 図から, 伐採裸地十伐採後二次林＋スギ幼齢林の分布面積 が大きくても斜面平均傾斜量の平均が $30^{\circ}$ 以下であれば崩 壊地が分布せず，逆にこれらの植生分布率が $5 \%$ 程度でも 斜面平均傾斜量の平均が $37^{\circ}$ を超えると崩壊が発生してい ることがわかる.さらに, 伐採裸地十伐採後二次林 + スギ 幼齢林の分布面積と斜面平均傾斜量の平均がともに大きい 場合には単位面積あたりの崩壊発生率が大きくなる。同様

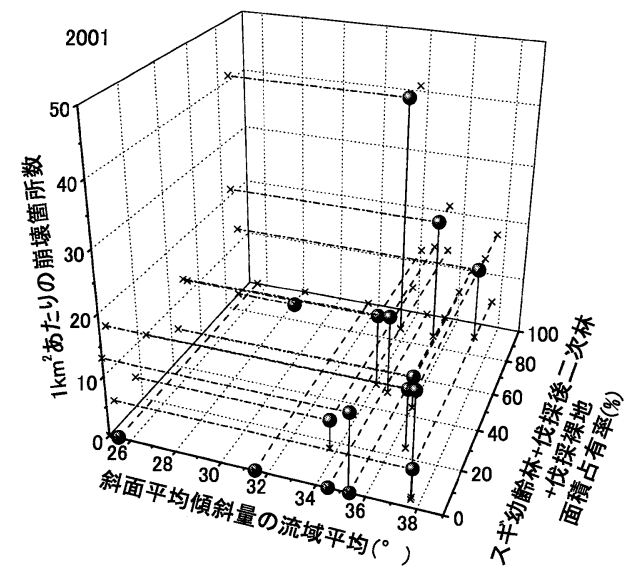

図-11 2001年における平均傾斜量の流域平均值, 伐採裸地+伐 採後二次林 + スギ幼齢林の分布率と単位面積あたりの崩 壊箇所数の関係を示す 3 次元図

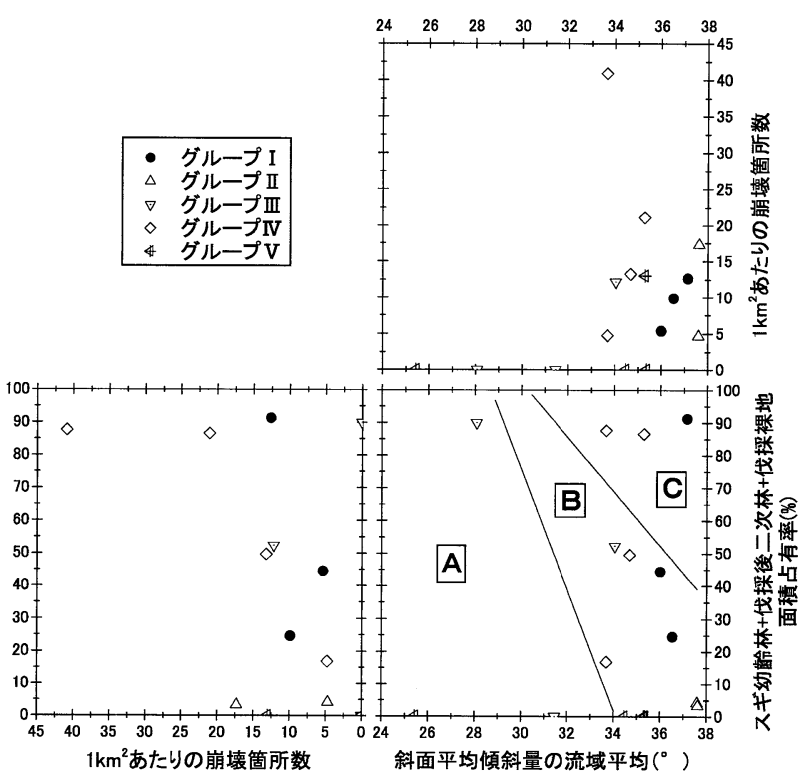

図-12 図-11の平面展開図 
の傾向が，2001年時点での流域面積に対する渓床堆積物分 布面積の比率でも認められる(図-13).

次に，2000年のレーザ測量で得られた地形データ (DEM データ)が，1970年以降の約30年間であまり变化がないと して，表-3の空中写真から判読した各時期の植生条件にお いても図-11に示した関係が認められるかを検討した。図一 14に1960年代までの伐採から植生が回復していない1970年 における結果とその後植生がほぼ回復した1985年の結果を

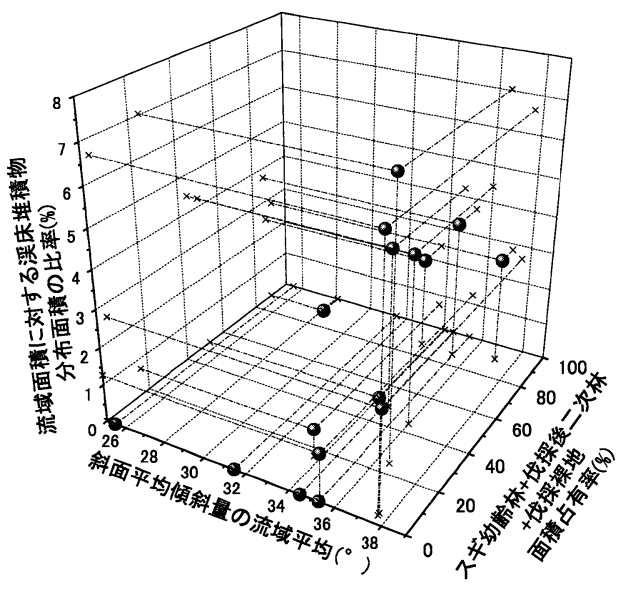

図-132001年における斜面平均傾斜量の流域平均值, 伐採裸地 +伐採後二次林 + スギ幼齢林の分布率之流域面積に対す る渓床堆積物分布面積の比率の関係を示す 3 次元図
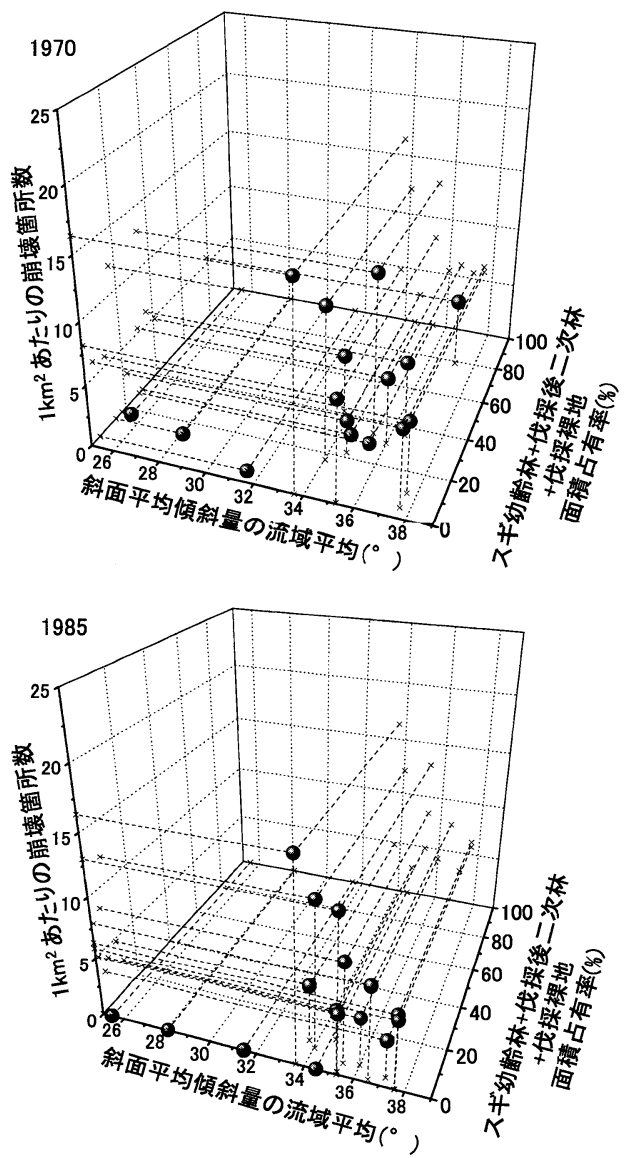

図-14 1970年と 1985年における斜面平均傾斜量の流域平均值, 伐採裸地 +伐採後二次林 + スギ幼齢林の分布率と単位面 積あたりの崩壊箇所数の関係を示す 3 次元図
示す. 図-11と比較すると，1970，1985年とあ2001年に比 べて単位面積あたりの崩壊箇所数が少ないが，1970年の結 果では2001年と同様に，伐採裸地十伐採後二次林 + スギ幼 齢林の分布面積の占有率と斜面平均傾斜量の流域平均の両 者が崩壊箇所数に影響していることが言えそうである。一 方，1985年の結果では，伐採裸地十伐採後二次林＋スギ幼 齢林の分布面積の占有率がすべての流域で低いため, 崩壊 箇所数が斜面平均傾斜量の流域平均の影響を受けていると 言えそうである.

以上のことから，災害発生を促進するような植生条件 （ここでは伐採裸地，伐採後二次林，スギ幼齢林）之斜面崩 壊に影響する地形因子(ここでは斜面平均傾斜量の流域平 均)とを適切に設定することにより，それらの值を用いて 斜面崩壊などの土砂災害地形が発生する可能性を評価でき ると推定される，例えば，図-12の右下図の領域Aで示さ れる斜面平均傾斜量の条件と植生分布の条件を満たす流域 ではほとんど崩壊が発生しないことが予想される。そして， 同図で領域BからCへ崩壊発生の可能性が高くなり, 領域 Cの斜面平均傾斜量の条件, 植生分布の条件を示す流域で は崩壊発生の危険性がかなり高いと考えられる.

\section{7. ま と め}

北部北上山地を対象に，空中写真を用いた判読により地 形と植生の経時変化を把握し，またDEMを用いて現地形 の定量的な計測を行った。これらから現地形の諸条件, 植 生の経時変化および土砂災害地形の発生や消長との相互関 係を検討した。

その結果，以下のことが明らかとなった。

1)流域の土砂災害地形の発生や消長には現地形条件の影響 が明瞭に認められる場合もある。

2)土砂災害地形の消長に, 流域内における植生の占有率の 変化が強く影響を与える流域が認められる。

3)地質条件や気象条件に差がない場合には，土砂災害地形 の発生や消長に現地形条件と植生変化の両者が大きな要因 として作用すると推定される。

4) 災害発生を促進するような植生条件と斜面崩壊に影響す る地形因子とを適切に設定することにより，それらの值を 用いて斜面崩壊などの土砂災害地形が発達する可能性を評 価できると推定される.

地形条件と植生条件の両者を考慮した災害評価について は多くの研究例があるが, 両条件を数值で表し, 定量的に 災害評価を行った事例はあまり報告されていない。しかし 今後は, 植生の評価などは高分解能の衛星画像により, 地 形条件については細密DEMにより定量的に特徴を把握で きるので，GIS等を用いて災害と地形・植生の関係を明ら かにすることによって，定量的に災害を予測することが可 能になると考えられる. 
謝辞 本研究を行うにあたり, (財)鉄道総合技術研究所 木谷日出男博士，榎本秀明博士には多くの議論をしていた だいた。また，2名の匿名査読者からは，有益なご助言を いただいた。ここに記して謝意を表します。

\section{引用 文 献}

1) 羽田野誠一(1974)：最近の地形学，8.崩壊性地形（その 1), 土之基礎, Vol.22, No.9, pp.42-49.

2) 太田岳洋 (2001)：DEMを用いた地形計測の自然災害評価へ の応用, 資源・素材 2001 (札幌)企画発表・一般発表(A)(B) 講演資料, pp.353-356.

3）菊池多賀夫 (2001)：地形植生誌，東大出版会， $220 \mathrm{p}$.

4）鈴木雅一(2002)：航空写真による最近57年間の丹沢山地北部 の崩壊地之森林の変遷, 砂防学会誌(新砂防), Vol.54, No.5, pp.12-19.

5）平松晋也・黒岩知恵・荒砂隆文(2002)：森林伐採や植栽面積 の変化が流域の土砂生産状況に及ぼす影響, 砂防学会誌(新 砂防), Vol.55, No.4, pp.3-11.

6）黑岩知恵・平松晋也(2004)：森林伐採や植栽を指標とした崩 壊面積予測手法に関する研究, 砂防学会誌(新砂防), Vol.57, No.2, pp.16-26.

7）武居有恒監修(1983）：地すべり・崩壊・土石流, 鹿島出版会, $334 \mathrm{p}$.

8）塚本良則 (1998)：森林・水・土の保全, 湿潤変動帯の水文地 形学, 朝倉書店, $138 \mathrm{p}$.
9）蔡斌・秋山㑆・小阪尚子・永井諭(2004)：高分解能マルチス ペクトル衛星画像による林分タイプの分類, 日本写真測量学 会年次学術講演会予稿集, pp.221-224.

10) HIGAKI, D.(1992): History of Morphogenetic Environments of the Kitakami Mountains, Northeastern Japan, In the Late Quaternary, The science report of the Tohoku University, 7th series (Geography), Vol. 42, No. 2, pp.129-162.

11）大上和良・永広昌之 (1988)：北部北上山地の先宮古統堆積岩 類に関する研究の総括と現状, 地球科学, Vol.42, No.4, pp.187-201.

12）吉田尚・片田正人(1984)：宮古地域の地質, 地域地質研究報 告 ( 5 万分の 1 図幅)，地質調査所.

13）箕浦幸治(1985）：北上・阿武隈はどこからきたか一東北日本 の地質構造の成り立ち一, 科学, Vol.55, No.1, pp.14-23.

14）田村俊和(1997）:なだらかな山地の形成とそこでの暮らし一 北上山地之阿武隈山地一, 日本の自然, 地域編 2 東北(小島 圭二・田村俊和・菊池多賀夫・境田清隆編), pp.72-91.

15）岩田悦行 (1971)：北上山地の二次植生・特に草地植生に関す る生態学的研究, 岐阜大農研報, No.30, pp.288-430.

16）環境省自然環境局編 (2004)：第 5 回自然環境保全基礎調査 植生調査報告書〔全国版〕, $346 \mathrm{p}$.

17）野上道男・隈元崇・中山大地・田中靖・乙黒善宏 (1998)： DEMデー夕処理技術講習会テキスト, 日本地形学連合, $207 \mathrm{p}$.

18）太田岳洋・八戸昭一(2006) : 数值地形モデルによる地形計測 の現状と応用例, 応用地質, Vol.46, No.6, pp.347-360.

（2007年 1 月18日受付， 2008年 5 月16日受理）

\title{
Topographical Attribute and Vegetation Change on Increase of Topography of Landslide Disaster -Examination in the Northern Kitakami Mountains-
}

\section{Takehiro OHTA, Atsushi HASEGAWA, Tomoyuki TAKAMI and Akihiro KAWAMURA}

\begin{abstract}
The changes of disaster topography and vegetation in northern Kitakami mountains area were investigated by aerial photograph on six periods during 1970 to 2001. The hard sedimentary rocks considered in homogeneous conditions are distributed in this area. The climate conditions of this area were constant from 1970 to 2001. The geomorphometric study was performed using detailed digital elevation model that was obtained by aerial laser measurement at late autumn in 2000.

As the results of these investigations, it is explained that both of geomorphological conditions and vegetation changes influence the generation and the reduction of disaster topography. For example, the number of collapse increases, as the average value of slope angle in drainage basin becomes large. In proportion to decrease of the distribution area of Quercus serrata/chestnut/deciduous broadleaf forest community, the number of collapse increases. However, if the average of slope angle in the drainage basin is small, the basin has no slope collapse even after the deforestation. When the average of slope angle and the ratio of surface area to drainage basin area in the basin become large, many disaster topographies occur in the basin. Therefore, it is assumed that we can assess the possibility of disaster topography developments by the numerical value of vegetation and geomorphology.
\end{abstract}

Key words : topography of landslide disaster, interpretation of aerial photograph, geomorphometric study, vegetation 